\title{
Whither Economic Organization?
}

\author{
Foss, Nicolai J.
}

Document Version

Final published version

Publication date:

2001

\section{License \\ CC BY-NC-ND}

Citation for published version (APA):

Foss, N. J. (2001). Whither Economic Organization? The Link Program. LINK Working Paper No. 2001-23

Link to publication in CBS Research Portal

\section{General rights}

Copyright and moral rights for the publications made accessible in the public portal are retained by the authors and/or other copyright owners and it is a condition of accessing publications that users recognise and abide by the legal requirements associated with these rights.

\section{Take down policy}

If you believe that this document breaches copyright please contact us (research.lib@cbs.dk) providing details, and we will remove access to the work immediately and investigate your claim. 


\title{
Whither Economic Organization?
}

\author{
Nicolai J Foss \\ LINK; Department of Industrial Economics and Strategy \\ Copenhagen Business School; Howitzvej 60; 2000 Frederiksberg; Denmark \\ njf.ivs@cbs.dk
}

(Prepared for a Special Issue of Zeitschrift für Betriebswirtschaft)

\section{Introduction 1}

Arguments and observations that strong economy-wide transformations in economic organization are taking place have been steadily accumulating in sociology and business administration for about two decades or so, but economists have only relatively recentlyjoined the discussion (e.g., Siebert 1995). While early discussions emphasized the increasing importance of various kinds of network governance, recent discussion appears to have predominantly cast the theme of transforming economic organization in the context of the emerging knowledge economy (e.g., Zucker 1991; Liebeskind et al., 1995; Grant 1996; Cowen and Parker 1997; Miles et al. 1997; Hodgson 1998; Mendelsson and Pillai 1999). Thus, firms are argued to adopt "network organization" and engage in "corporate disaggregation," so as to become "information age organizations" that may build the "dynamic capabilities" required for competing in an environment characterized by changes in the composition of inputs toward knowledge inputs, an increase of the "knowledge-content" in outputs, a stepping up of innovative activity, an increasing differentiation of demand, increasing globalization, and increasingly inexpensive networked computing - that is, the "knowledge economy" (Prusak 1998; Neef 1998). Very strong claims with respect to economic organization are often made. An overall theme is that firms need to become much more market-like in order to survive and prosper in the emerging knowledge economy.

This paper is my keynote speech to 63. Jahrestagung des Verbandes der Hochschullehrer für Betriebswirtschaft e.v., 5-8 Juni in Freiburg i. Br. I am grateful for comments from the audience. More elaborate statements of the positions in this paper can be found in Foss $(1999,2001,2002)$. 
A theoretical implication of this is that the traditional distinction between "firm"transactions and "market"-transactions is becoming increasingly irrelevant.

In keeping with the theme of this conference - "Die Evolution der Unternehmung in Wettbewerb" - I shall critically address these issues from a perspective that is strongly, if not exclusively, informed by Austrian economics (Hayek 1948; Mises 1949; Kirzner 1997). An Austrian perspective is a particularly fitting starting point for such an exercise. Austrian economists have always been occupied with analyzing the discovery, dispersion and use of knowledge; indeed, to Austrians, all economies are, in a broad sense, "knowledge economies." And many recent changes in economic organization may fruitfully may analyzed in an Austrian way as a matter of changing firm organization in response to a changed external environment in such a way that knowledge may better be grown, utilized and transferred. As Hayek (1948: 77-8) noted:

The peculiar character of the problem of a rational economic order is determined precisely by the fact that the knowledge of the circumstances of which we must make use never exists in concentrated or integrated form but solely as the dispersed bits of incomplete and frequently contradictory knowledge which all the separate individuals possess. The economic problem of society is thus not merely a problem of how to allocate "given" resources - if "given" is taken to mean given to a single mind which deliberately solves the problem set by these "data". ... Or, to put it briefly, it is a problem of the utilization of knowledge which is not given to anyone in its totality.

Clearly, this is a problem that is not only characteristic of "society"; it is also a very pressing one, and increasingly so, for modern firms. However, Austrian insights into these issues need to be supplemented with insights from new institutional economics (Williamson 1996) and contract theory (Hart 1995) in order to provide a full picture. In generic terms, I discuss the implications for the Coasian firm of the Hayekian notion that the dispersal of economically relevant knowledge is a strongly binding constraint on the use of planned coordination. I take the increasing importance of such dispersed (or, if you like, "distributed") knowledge in production to be an important 
characteristic of the knowledge economy (Coombs and Metcalfe 2000; Foss 2001, 2002). Given this, I argue that contrary to many writers on economic organization in the knowledge economy, it does not follow that firms should emulate markets as far as possible in order to thrive - even in the presence of those radical knowledge conditions identified by these writers as well as Austrian economists.

\section{Economic Organization in the Knowledge Economy}

A consensus seems to be emerging that tasks and activities in the knowledge economy need to be coordinated in a manner that is very different from the management of traditional manufacturing activities, with profound transforming implications for the authority relation and the internal organization and boundaries of firms. There are several reasons for this.

Because of the increasing importance in knowledge-intensive industries of combining knowledge inputs, sourcing knowledge for this purpose, and keeping sourcing options open, knowledge-based networks increasingly become the relevant dimension for understanding the organization of economic activities. Such networks typically cut across the legal boundaries of the firm. Networks are particularly useful organizational arrangements for sourcing and transferring knowledge because of the comparatively higher costs of pricing knowledge in a market or transferring it in a hierarchy (Liebeskind et al. 1995: 7). The increased reliance on knowledge networks tends to erode authority-based definitions of the boundaries of the firm, because authority increasingly shifts to expert individuals who control crucial information resources and may not be employees of the firm (e.g., Zucker 1991: 164). Also, knowledge worker gain increased bargaining stemming from their control over critical knowledge assets. Finally, the specialist nature of knowledge work (Hodgson 1998) implies that principals/employers become ignorant about (some of) the actions that are open to agents/employees, thus making the exercise of authority through direction increasingly inefficient.

The combined effect of the increased importance of knowledge assets that are controlled by knowledge workers themselves and of the increasingly specialist nature of knowledge work is to wreck the traditional economist's criterion of what 
distinguishes market transactions from hierarchical transactions. Thus, whether direction by means of order giving (Coase 1937) and backed up by the ownership of alienable assets (Hart 1995) obtains or not is increasingly irrelevant for understanding the organization of economic activities in a knowledge economy. Not only does the emerging knowledge economy profoundly change the authority relation, and the boundaries of firms; it also influences the design of firms' internal organization, that is, their allocation of decision rights. As Miles et al. (1997: 7) point out, a "...number of leading companies today are experimenting with a new way of organizing - the cellular form. Cellular organizations are built on the principles of entrepreneurship, self-organization, and member ownership. In the future, cellular organizations will be used in situations requiring continuous learning and innovation." By suggesting that radical internal hybrids, "built on the principles of entrepreneurship, self-organization, and member ownership," are emerging as stable organizational modes, this quotation (and others like it) suggests that mechanisms for coordinating economic activities are more combinable, and that the set of stable discrete governance structures is larger, than what is conventionally assumed in much of organization theory and in the economics of organization (e.g., Coase 1937; Williamson 1996). These new governance structures are increasingly often referred to as "new organizational forms." To the extent that new organizational forms represent new ways of combining mechanisms that have traditionally been seen as characteristic of governance structures that are polar opposites, they also exemplify the fading boundaries between markets and firms (Helper, MacDuffie and Sabel 2000).

\section{Whither Economic Organization?}

It is no coincidence that so many of those who write on economic organization in the emerging knowledge economy approvingly cite Hayek's work, particularly his 1945 paper, "The Use of Knowledge in Society" (e.g., Nonaka and Takeuchi 1995). Hayekian (and Austrian) themes such as the coordination problem introduced by dispersed knowledge, competition as a discovery procedure, and entrepreneurship are very clearly mirrored in much recent work on economic organization in the knowledge economy. The main difference relative to Hayek and the other Austrians is that recent 
writers have taken these themes inside the firm, as it were (particularly Jensen and Meckling 1992; Cowen and Parker 1997). They argue that detailed planning is as problematic inside firms as it is at the level of the economy at large. In the process, they have come to the conclusion that knowledge economy firms are very different indeed from the kind of firms that are seen as typical of the industrial society (e.g., Miles et al. 1997). They, too, need to foster an entrepreneurial discovery process comparable to that generated by the market (Kirzner 1997). In fact, knowledge economy firms are so market-like (because of their need to cope with dispersed knowledge) as to wreck havoc with the conventional distinction between firms and markets. At best, the difference is a matter of contractual details. However, as I shall argue this does not necessarily follow, even if we assume "Austrian conditions," that is, widespread ignorance in the face of dispersed knowledge (Hayek 1948; Kirzner 1997).

\section{Authority}

One reason why authority is (allegedly) waning in importance is that it is becoming increasingly more difficult to monitor and direct workers, because of the specialist nature of knowledge work. In terms of agency theory, what is being asserted is that the problem facing a principal is not just that he is uninformed about what state of nature has been revealed or of the realization of the agent's effort (i.e., hidden information), as in the agency model (Holmström 1979), but that he may be ignorant about members of the set of possible actions open to the agent, or the agent may be better informed than the principal with respect to how certain tasks should (optimally) be carried out, or both. However, even in such a setting, it is possible to provide efficiency explanations of authority.

The Need for Urgent Coordination. Coordinated adaptation or action may be required when actions or activities are complementary (Milgrom and Roberts 1990), for example, when it is important to make some urgent choice (possibly highly inefficient), because doing nothing is worse. In such cases, it may be better to give somebody the authority to pick a strategy and make everybody play this strategy, if the inefficiencies from picking a bad strategy are smaller than the inefficiencies from delaying a coordinated solution 
Decisive Information. Although the centralized decision-maker does not possess at least some local information, he may still hold the information that is decisive. Loosely, information is (strongly) decisive if - in a setting involving many cooperating individuals - a decision can reasonably be made on the basis of this information without involving other pieces of information (Casson 1994). Such decisiveness and the cost at which knowledge can be communicated helps to explain the allocation of decision rights (ibid.), including authority. If the knowledge possessed by, for example, middle-managers is not decisive, if the knowledge possessed by the CEO is decisive, and if it is costly to communicate the CEO's knowledge, then overall decision rights should be concentrated in the hands of the CEO, that is, he should assume ultimate authority in the firm.

Economies of Scale in Decision-Making. There may be economies of scale as well as learning economies in managing the internal relations between agents inside the firm and managing relations to outside agents (customers, suppliers, government agencies. Other agents may be happy to let a central agent incur the effort costs of negotiating, learning about potential suppliers, etc., and compensate him accordingly.

Defining Incentive Systems. Arguably, the emergence of the knowledge economy does pose special problems for the use of monitoring mechanisms and incentive pay because knowledge problems are likely to go beyond the asymmetric paradigm (Foss 1999). It may be conjectured that the more we depart from simple settings where employees are very easily monitored, and the more complicated the control problem becomes, the more likely is it that the entrepreneur will choose to rely on multiple incentive instruments to influence employee behavior. In a dynamic economy, maintaining coherence between such instruments is a recurrent task. Economies of scale dictate that this activity be centralized. Moreover, centralization is required to the extent that externalities arise when the instruments are controlled by separate firms and transaction costs hinder the internalization of these externalities. Both arguments point towards the centralization of decision rights, that is, towards authority. 


\section{Delegation}

The reason that firms can thrive even though they (like whole economies) also confront the kind of problems relating to the efficient use of dispersed knowledge that Hayek (1948) identified is that they have recourse to delegation of decision rights (Mises 1949: 305; Jensen and Meckling 1992). However, in firms delegation is circumscribed in an attempt to cope with the control problem that follows from delegation. An organizational equilibrium obtains where decision rights are delegated in such a way that the benefits of delegation in terms of better utilizing local knowledge are balanced against the costs of delegation in terms of agency losses. This provides a useful perspective on many of those new organizational forms that are argued to be characteristic of the knowledge economy (cf. Cowen and Parker 1997), such as teamorganization, "molecular forms", and other manifestations of organizational delegation and decentralization: These are prompted by a market-driven pressure to delegate decision rights (e.g., to better serve customer preferences) and structure reward schemes in such a way that optimal tradeoffs are reached. Thus, decision rights are delegated inside firms, but they are delegated as means to an end, their use is monitored (Jensen and Meckling 1992), and top-management reserves ultimate decision rights for itself (Baker, Gibbons, and Murphy 1999).

\section{The Boundaries of Firms and Ownership}

Some writers (e.g., Zucker 1991; Helper et al. 2000) argue that as knowledge assets become relatively more important in production, and as learning becomes increasingly important as a source of competitive advantage, the boundaries of firms will blur, at least to the extent that these are defined in terms of legally recognized ownership of the firm's alienable assets. The relevant loci for economic activities are networks - and the boundaries of the firm as being defined by ownership of assets are merely a distraction. However, it is easy to see that even in firms that have no physical assets, the boundaries of the firm may be crucially important.

Thus, assume a purely "knowledge-based" team, consisting of two agents and two strictly complementary knowledge assets. The "entrepreneur" owns a knowledge asset that is "inside his head" (e.g., an entrepreneurial idea) and the "scientist" owns a 
"patent." It is prohibitively costly to communicate the knowledge embodied in the entrepreneurial idea. Moreover, it is not possible to write a comprehensive contract, governing the use of the assets in all contingencies. Given this, we may ask who should own the (alienable) patent. Now, if the entrepreneur makes an effort investment, that is, elaborates on his idea and creates extra value, the scientist can effect a hold-up on the entrepreneur, since the latter needs access to the patent to create value (and the contract is incomplete). Of course, the reverse also holds. One can show (details in Brynjolfsson 1994) that because of the externality problem that the hold-up threat creates, every agent invests too little; specifically, each party invests to the point where the marginal cost of effort investment equals $1 / 2$ of the marginal value (because they are assumed to split the extra surplus $50: 50$ ). Suppose now that the entrepreneur owns both the patent and the entrepreneurial idea. This will strengthen the entrepreneur's incentives (the scientist cannot hold him up anymore) and it will leave the scientist's incentives unaffected. Rational agents will choose this arrangement.

The conclusion is that it is possible to speak of the boundaries of the firm in terms of ownership - even in a situation where all relevant productive assets are knowledge assets. Similar reasoning allows us to see why authority and ownership usually go together. Assume that one of the agents, the entrepreneur, has decisive information (in the sense discussed earlier). While it argued earlier that it would be rational to give this agent authority, should he also be an owner? Consider a bigger knowledge-based firm, with a group of $n$ scientists $(n>1)$ who each owns a patent. The entrepreneur aggregates information from the messages of the scientists and exercises authority by directing their efforts. His knowledge is decisive in the sense that without it, all actions of the other agents produce zero value. The entrepreneur may improve on this decisive knowledge. Each agent needs access to his own patent and to the entrepreneur's direction in order to be productive. Given these assumptions, the holdup problem is still present: Any one of the scientists can hold up the entrepreneur on his investment, making the entrepreneur choose inefficient investments. However, if the entrepreneur is given ownership to the alienable assets, that is, the patents, the hold-up problem disappears. Rational agents will choose this arrangement. 


\section{The Combinability of Coordination Mechanisms}

It is a prevalent theme in recent work on economic organization in the knowledge economy that coordination mechanisms (direction, routines, teams, prices, etc.) are basically combinable at will. Notably, mechanisms characteristic of the market may be introduced into the internal organization of firms, for example, in order to foster entrepreneurship. However, theoretical arguments suggest that emulating market organization inside firms, for example, by radically decentralizing the firm and allocating far-reaching decision rights to employees may be hard to accomplish in a successful manner. Unlike independent agents in markets, corporate employees never possess ultimate decision rights. They are not full owners. This means that those who possess ultimate decision rights can always overrule employees. Thus, there are incentive limits to the extent to which market mechanisms can be applied inside firms, and delegation, while not exactly a rare flower, is certainly a very delicate one (Williamson 1996; Baker et al. 1999).

Other means of introducing market mechanisms inside firms are also problematic, if for somewhat different reasons. Thus, multi-task agency theory suggests that there are quite rational reasons for the "low-powered" incentives one typically observes inside firms (in contrast to the "high-powered" incentives of the marketplace) (Holmström and Milgrom 1994). This is because managers wish employees to undertake multiple tasks, some of which may be very costly to observe and measure, but which may nevertheless be vital to the firm (e.g., sharing knowledge with colleagues, handling calling customers in a polite manner, etc.). Providing incentives that are only tied to those tasks that can be measured (at low cost) risks twisting efforts away from the costly-to-measure tasks.

Taken together the reasoning above suggests that coordination mechanisms are not simply combinable in an arbitrary fashion. Rather, they are complementary (another favorite Austrian theme). Ultimately, this is because authority and ownership will continue to be important in the knowledge economy, as argued earlier. First, it has been argued that there is an inherent tension between ownership and delegated rights. Second, delegation is often necessary, but equally often needs to be backed up by a 
strengthening of incentives because of the agency problem. However, under multitasking, there are limits to how much incentives can be strengthened. Thus, rather than being combinable at will, coordination mechanisms, such as authority, delegation, pricing, etc., tend to cluster in predictable ways - reflecting underlying complementarities — in "governance structures" (Williamson 1996). In particular, concentrated ownership, authority, circumscribed decision rights, and incentives that are less "powered" than those of the marketplace are all complementary elements of a system, namely, the Coasian firm, and they will continue to be so, even in the knowledge economy.

\section{Conclusions}

There can be little doubt that the collection of changes that we often refer to as the "knowledge economy" impact upon economic organization. In particular, the strong increase in strategic alliances, the trend towards corporate (re-)focusing, the increasing number of spin-offs, and the many attempts to change internal organization towards more team-based organization arguably reflect attempts to better utilize knowledge and stimulate learning, while making use of the high-powered incentives of the market. However, theoretical reasoning, drawn from both Austrian economics and organizational economics, does not support some of the more radical claims with respect to economic organization that are sometimes put forward. In essence, it is often argued that what may be called the "Coasian firm," characterized by authority, boundaries defined in terms of asset ownership and complementary coordination mechanisms will wither in the knowledge economy. In contrast, theoretical reasoning suggests that even though specialist knowledge workers may become increasingly important in production and even though knowledge may become increasingly distributed, there is no reason to suppose that authority will wither, the boundaries of firms will blur and coordination mechanisms will be combinable at will. Thus, although the Coasian firm will undergo changes, for the knowledge-related reasons identified by the Austrians, it will persist in its basic constitution. 


\section{References}

Baker, George, Robert Gibbons, and Kevin J. Murphy. 1999. "Informal Authority in Organizations," Journal of Law, Economics and Organization 15: 56-73.

Brynjolfsson, Erik. 1994. "Information Assets, Technology, and Organization," Management Science 40: 1645-1662.

Casson, Mark. 1994. “Why are Firms Hierarchical?," International Journal of the Economics of Business 1: 47-76.

Coase, Ronald H. 1937. "The Nature of the Firm," in Nicolai J. Foss, ed. 1999. The Theory of the Firm: Critical Perspectives in Business and Management, Vol II. London: Routledge.

Coombs, Rod and Stan Metcalfe. 2000. "Organizing for Innovation: Co-ordinating Distributed Innovation Capabilities," in Nicolai J Foss and Volker Mahnke, eds. Competence, Governance, and Entrepreneurship. Oxford: Oxford University Press.

Cowen, Tyler and David Parker. 1997. Markets in the Firm: A Market Process Approach to Management. London: The Institute of Economic Affairs.

Foss, Nicolai J. 1999. "The Use of Knowledge in Firms", Journal of Institutional and Theoretical Economics 155: 458-486.

Foss, Nicolai J. 2001. "Misesian Ownership and Coasian Authority in Hayekian Settings: The Case of the Knowledge Economy," forthcoming in Quarterly Journal of Austrian Economics.

Foss, Nicolai J. 2002. "Coase vs Hayek: Economic Organization in the Knowledge Economy," forthcoming in International Journal of the Economics of Business.

Grant, Robert M. 1996. "Prospering in Dynamically-Competitive Environments: Organizational Capability as Knowledge Integration," Organization Science 7: 375387.

Hart, Oliver. 1995. Firms, Contracts, and Financial Structure. Oxford: Oxford University Press.

Hayek, Friedrich A. von 1948. Individualism and Economic Order. Chicago: University of Chicago Press.

Helper, Susan, John Paul MacDuffie, and Charles Sabel. 2000. "Pragmatic Collaborations: Advancing Knowledge While Controlling Opportunism," Industrial and Corporate Change 9: 443-487.

Hodgson, Geoff. 1998. Economics and Utopia. London: Routledge.

Holmström, Bengt. 1979. "Moral Hazard and Observability," Bell Journal of Economics 10: 74-91.

Holmström, Bengt. 1999. "The Firm as a Subeconomy," Journal of Law, Economics, and Organization 15: 74-102.

Holmström, Bengt and Paul Milgrom. 1994. "The Firm as an Incentive System," American Economic Review 84: 972-991. 
Jensen, Michael C. and William H. Meckling. 1992. "Specific and General Knowledge and Organizational Structure," in Lars Werin og Hans Wijkander, eds. 1992. Contract Economics. Oxford: Blackwell.

Kirzner, Israel M. 1997. "Entrepreneurial Discovery and the Competitive Market Process: An Austrian Approach," Journal of Economic Literature 35: 60-85.

Liebeskind, Julia Porter, Amalya Lumerman Oliver, Lynne G. Zucker, Marilynn B. Brewer. 1995. Social Networks, Learning, and Flexibility: Sourcing Scientific Knowledge in New Biotechnology Firms. Cambridge: NBER Working Paper No. W5320.

Mendelson, Haim and Ravindran R. Pillai. 1999. "Information Age Organizations, Dynamics, and Performance," Journal of Economic Behavior and Organization 38: 253-281.

Miles, Raymond E., Charles C. Snow, John A. Mathews, Grant Miles and Henry J. Coleman, Jr. 1997. "Organizing in the Knowledge Age: Anticipating the Cellular Form," Academy of Management Executive 11: 7-20.

Mises, Ludwig von. 1949. Human Action. San Francisco: Fox and Wilkes.

Neef, Dale, ed. 1998. The Knowledge Economy. Boston: Butterworth-Heinemann.

Nonaka, Ikujiro and Takeuchi. 1995. The Knowledge-Creating Company. Oxford: Oxford University Press.

Prusac, Laurence. 1998. "Introduction to Series - Why Knowledge, Why Now?," in Dale Neef, ed. 1998. The Knowledge Economy. Boston: Butterworth-Heinemann.

Siebert, Horst, ed. 1995. Trends in Business Organization: Do Participation and Cooperation Increase Competitiveness? Tübingen: J C B Mohr.

Williamson, Oliver E. 1996. The Mechanisms of Governance. Oxford: Oxford University Press.

Zucker, Lynne. 1991. "Markets for Bureaucratic Authority and Control: Information Quality in Professions and Services," Research in the Sociology of Organizations 8: 157-190. 